Article

\title{
Ozone Trends from Two Decades of Ground Level Observation in Malaysia
}

\author{
Fatimah Ahamad ${ }^{1, * \mathbb{D}}$, Paul T. Griffiths ${ }^{2} \mathbb{D}$, Mohd Talib Latif ${ }^{3} \mathbb{D}$, Liew Juneng ${ }^{3} \mathbb{D}$ and \\ Chung Jing Xiang 4
}

1 Centre for Tropical Climate Change System, Institute of Climate Change, Universiti Kebangsaan Malaysia, UKM Bangi 43600, Malaysia

2 National Centre for Atmospheric Science, Department of Chemistry, University of Cambridge, Lensfield Road, Cambridge CB2 1EP, UK; paul.griffiths@ncas.ac.uk

3 Department for Earth Sciences and Environment, Faculty of Science and Technology, Universiti Kebangsaan Malaysia, UKM Bangi 43600, Malaysia; talib@ukm.edu.my (M.T.L.); juneng@ukm.edu.my (L.J.)

4 Institute of Oceanography and Environment, Universiti Malaysia Terengganu, Kuala Nerus 21030, Malaysia; jingxiang@umt.edu.my

* Correspondence: fatimah.a@ukm.edu.my

Received: 28 June 2020; Accepted: 15 July 2020; Published: 17 July 2020

check for updates

\begin{abstract}
We examine the change in surface ozone and its precursor behavior over 20 years at four locations in western Peninsular Malaysia which have undergone urban-commercial development. Trend and correlation analyses were carried out on ozone and oxides of nitrogen observation data over the periods of 1997-2016 as well as the decadal intervals of 1997-2006 and 2007-2016. Diurnal variation composites for decadal intervals were also plotted. Significant increasing ozone concentrations

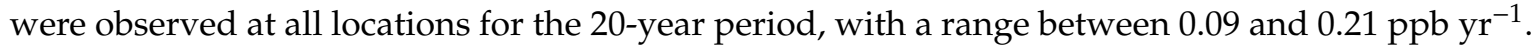
The most urbanized location (S3) showed the highest ozone trend. Decadal intervals show that not all stations record significant increasing trends of ozone, with S1 recording decreasing ozone at a rate of $-0.44 \mathrm{ppb} \mathrm{yr}^{-1}$ during the latter decade. Correlation analysis showed that only oxides of nitrogen ratios $\left(\mathrm{NO} / \mathrm{NO}_{2}\right)$ had significant inverse relationships with ozone at all stations corresponding to control of ozone by photostationary state reactions. The diurnal composites show that decadal difference in $\mathrm{NO} / \mathrm{NO}_{2}$ is mostly influenced by change in nitric oxide concentrations.
\end{abstract}

Keywords: ozone precursors; long term ozone measurements; gaseous pollutant ratios

\section{Introduction}

Surface ozone $\left(\mathrm{O}_{3}\right)$ is a pollutant that affects human health and crop yields [1-4]. $\mathrm{O}_{3}$ studies in urban areas, particularly in the urban-commercial hub within and around Kuala Lumpur, the capital city of Malaysia, have shown frequent incidences of high $\mathrm{O}_{3}$ and other pollutant concentrations such as particulate matter [5-7]. Within the greater Klang Valley conurbation, which is the most densely populated area in Malaysia, surface $\mathrm{O}_{3}$ exposure has reached levels that pose significant risks to health [4]. However, a study on public perception on air quality in the area indicates that more than two-thirds of respondents did not perceive any threats to their health and have a positive outlook on the air quality status in the area. Concerns on air quality discussed in popular media in Malaysia are typically associated with severe haze episodes caused by large scale biomass burning in the region that causes perceivable reduction in visibility $[8,9]$. Since $\mathrm{O}_{3}$ is a colorless gas that does not have a pungent odor, there is likely less awareness of the severity of $\mathrm{O}_{3}$ pollution when it is not accompanied by haze episodes. 
Mitigation and control of $\mathrm{O}_{3}$ pollution is challenging as it is not a pollutant that is directly emitted into the atmosphere. $\mathrm{O}_{3}$ is formed through reactions of precursors such as oxides of nitrogen (NOx) and volatile organic compounds (VOC) that contribute to the formation of atomic oxygen (O). Reaction of this atomic oxygen with molecular oxygen $\left(\mathrm{O}_{2}\right)$ results in the formation of $\mathrm{O}_{3}$. Although $\mathrm{O}_{3}$ formation from oxygen appears straightforward, $\mathrm{O}_{3}$ photochemistry is complex. The NOx pathway of $\mathrm{O}_{3}$ formation, for example, also involves the destruction of $\mathrm{O}_{3}$ by nitric oxide (NO), when $\mathrm{NO}$ concentrations are sufficiently high $[10,11]$. In urban environments, $\mathrm{O}_{3}$ formation can be classified into NOx-sensitive and VOC-sensitive regimes. In the NOx-sensitive regime, reducing NOx will result in greater reduction in $\mathrm{O}_{3}$ compared to reducing VOC, while the opposite is true for the VOC-sensitive regime [12]. Formation of surface $\mathrm{O}_{3}$ also requires the presence of sunlight. Hence, its level is strongly influenced not only by the complex chemical pathways involved in its formation and destruction, but also by meteorological factors that drive these reactions [10,13-15].

In Malaysia, studies on surface $\mathrm{O}_{3}$ pollution have mostly focused on relatively short study periods of ten years or less [16-18]. These studies have explained the relationship between $\mathrm{O}_{3}$ and its precursors as well as meteorological parameters at diurnal and seasonal scales. The monsoon seasons in Malaysia have been shown to influence the intra-annual variability of $\mathrm{O}_{3}$ with both local and regional transport associated with seasonal winds influencing $\mathrm{O}_{3}$ episodes in Malaysia $[5,17,19]$. Variability of $\mathrm{O}_{3}$ during high particulate matters events associated with haze and non-haze episodes has also been studied, as $\mathrm{O}_{3}$ showed a positive relationship with high particulates events at diurnal scale [20,21].

Although the seasonal and diurnal variability of $\mathrm{O}_{3}$ in Malaysia has been extensively studied, very few studies have focused on determining long term $\mathrm{O}_{3}$ trends, particularly in the western coast of the peninsula where the Klang Valley is located. A long term study on a background surface $\mathrm{O}_{3}$ monitoring site showed a positive $\mathrm{O}_{3}$ trend for the period between 1997 and 2011, associated with expanding anthropogenic activity in the surrounding area [22]. In contrast, daily maximum $\mathrm{O}_{3}$ trends in Malaysian Borneo showed that only four out of the six available monitoring stations recorded increasing $\mathrm{O}_{3}$ trends for the period between 2002 and 2013. It would appear that not all locations show consistently increasing trends in $\mathrm{O}_{3}$ within the country and it is unclear if differences in $\mathrm{O}_{3}$ trends would directly relate to its precursor trends. Given that Malaysia is a tropical country that has markedly different seasonal weather profile from countries in mid-latitudes and has been undergoing rapid urban expansion since the early 1990s, analyzing its long term $\mathrm{O}_{3}$ behavior is expected to provide some insight into $\mathrm{O}_{3}$ behavior in a developing country over the tropical region.

The main aim of this study is to identify $\mathrm{O}_{3}$ and oxides of nitrogen trends over two decades at four locations in western Peninsular Malaysia that have undergone urban-commercial development. $\mathrm{O}_{3}$ and precursor trends as well as correlation were determined, and diurnal variation composites for decadal intervals were further plotted to determine the relationship between $\mathrm{O}_{3}$ and oxides of nitrogen over the periods of 1997-2016, 1997-2006, and 2007-2016. Decadal intervals were also included in the analysis for comparing patterns in $\mathrm{O}_{3}$ trends to determine if the trends are still consistent when different intervals are analyzed.

\section{Data and Methodology}

Gaseous pollutant records between 1997 and 2016 at four stations within the Department of Environment (DoE) Malaysia's ambient air quality network were selected and analyzed (Figure 1). Station selection was done based on pollutant data availability for the duration of the study and its location within Peninsular Malaysia. The Malaysian peninsula can be divided into the western, eastern, and southern region as the Titiwangsa mountain range bisects the peninsula from the north to more than two-thirds of Peninsular Malaysia toward the south. The topography influences meteorology such as the difference in seasonal rainfall between the east and west [23]. Western Peninsular Malaysia has more densely populated areas and commercial-industrial zones compared to the east. 


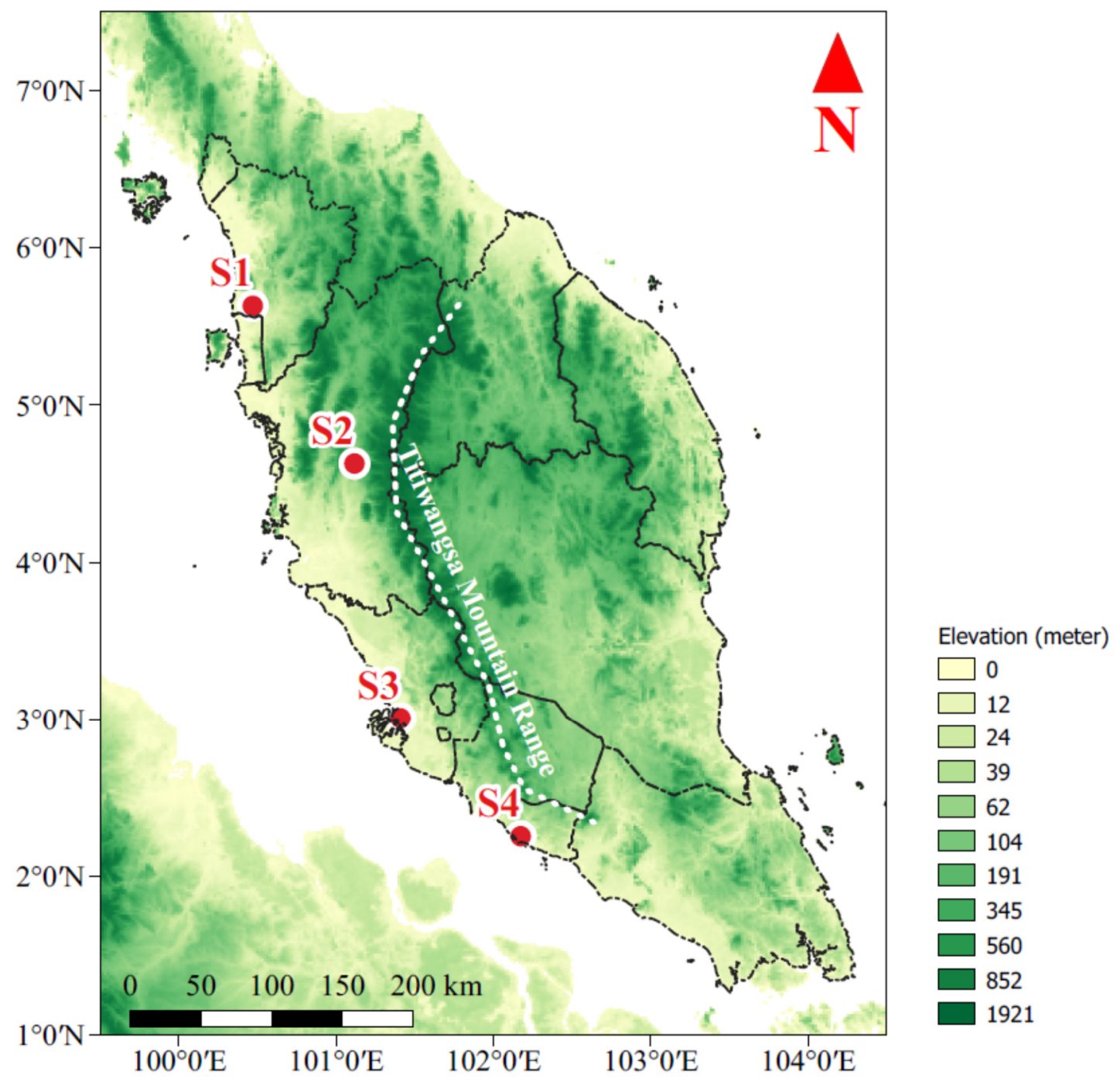

Figure 1. Location of the four monitoring stations within Peninsular Malaysia.

Hourly $\mathrm{O}_{3}$ measurements were made using a UV absorption $\mathrm{O}_{3}$ analyzer (Teledyne Model 400A, San Diego, CA, USA). NO and NOx measurements as well as $\mathrm{NO}_{2}$ readings were obtained from the Teledyne Model 200A analyzer (San Diego, CA, USA). Carbon monoxide (CO) measurements were taken using a Teledyne Model 300 analyzer (San Diego, CA, USA). Sulphur dioxide $\left(\mathrm{SO}_{2}\right)$ measurements were made using Teledyne Model 100A/E (San Diego, CA, USA). Additional information on instruments can be found in Latif et al. (2014) [22]. For the period between 1997 and 2016, the DoE contracted the measurements of pollutants and the calibration of equipment for the continuous air quality monitoring network to Alam Sekitar Malaysia Sdn. Bhd. Calibration and maintenance schedules include daily autocalibration for all pollutants and monthly maintenance. Data transferred to the DoE used here are data that have undergone calibration and maintenance schedules that were designed based on United States Environmental Protection Agency standards.

Data from the DoE were preprocessed to discard zero readings for pollutant concentration, and no computational method was used to replace or impute hourly missing value for the pollutants. To reduce the impact on data homogeneity, if large continuous missing values were present in $\mathrm{O}_{3}$ data, only stations that recorded $10 \%$ or less hourly missing data within the 20 -year period were selected. These were then further checked to determine that no more than $25 \%$ of these hourly data were missing each year. For all other pollutants, the total missing value had to be less than $30 \%$, while the annual missing value had to be less than $50 \%$ to fulfil station selection criteria. The $50 \%$ cut-off is deemed acceptable, given that Malaysia is a tropical country without large seasonal variability such as those 
observed in mid latitudes. A similar cut-off point has also been employed in a Hong Kong study on long term $\mathrm{O}_{3}$ trends [24]. Information on station location and data availability is presented in Table 1. Missing values for the monthly data are visually represented in the time series plots shown and discussed in Section 3 (Figures 4 and 6).

Table 1. Station location and data availability.

\begin{tabular}{cccccc}
\hline Station ID & S1 & S2 & S3 & S4 \\
\hline Location & & Sungai Petani, Kedah & Tasek Ipoh, Perak & Klang, Selangor & Bukit Rambai, Melaka \\
Latitude $\left({ }^{\circ} \mathrm{N}\right)$ & & 5.6314 & 4.6297 & 3.0103 & 2.2585 \\
Longitude $\left({ }^{\circ} \mathrm{E}\right)$ & & 100.47 & 101.11 & 101.40 & 102.17 \\
\hline & $\mathrm{O}_{3}$ & 9.9 & 10.0 & 10.0 & 9.4 \\
$\%$ missing data for & $\mathrm{NOx}$ & 9.8 & 7.7 & 10.5 & 8.9 \\
20-year period & $\mathrm{NO}_{2}$ & 27.6 & 21.9 & 15.1 & 18.1 \\
& $\mathrm{CO}$ & 7.1 & 8.6 & 10.7 & 6.4 \\
& $\mathrm{SO}_{2}$ & 26.7 & 8.8 & 8.0 & 14.1 \\
\hline
\end{tabular}

Monthly mean (Mmean) was calculated from hourly data if 50\% or more of the hourly data were available within the month. If this criterion was not fulfilled, the resultant missing monthly data were replaced with median values calculated over a sliding window of length 10 months using "movmedian" function within MATLAB 2019b. In addition to $\mathrm{O}_{3}$, Mmean was calculated for oxides of nitrogen ( $\mathrm{NO}, \mathrm{NO}_{2}$ and $\mathrm{NOx}$ ) and selected pollutant ratios such as $\mathrm{NO} / \mathrm{NO}_{2}, \mathrm{CO} / \mathrm{NOx}$, and $\mathrm{SO}_{2} / \mathrm{NOx}$. Monthly mean for daily maximum (Mmax) values were also calculated for $\mathrm{O}_{3}$ as the daily maximum for the period between 12 p.m. and 6 p.m. if more than $3 \mathrm{~h}$ of data were available within a day. The moving median method was also used to replace missing values for $\mathrm{Mmax}_{3}$ concentration as required.

Trend analysis on Mmean and Mmax was done using Theil-Sen estimator, which is a non-parametric method that is robust in the presence of outliers and requires little prior information regarding measurement errors [24,25]. The trend analysis was performed in R (version 3.6.2), using the "stl" function in the openair package to deseasonalize the data with Loess smoothing [26]. Loess smoothing applies a weighted least squares method for its polynomial fit and is also robust against presence of outliers $[27,28]$. Spearman's Rank-Order Correlation analysis was carried out on the monthly mean (Mmean) values of the pollutants to determine the relationship between $\mathrm{O}_{3}$ and other gaseous parameters.

Emissions data ranging from 1997 to 2015 for $\mathrm{NOx}, \mathrm{CO}$, and $\mathrm{SO}_{2}$ were obtained from EDGARv5.0) $[29,30]$. The data extracted have a yearly temporal resolution and are gridded at horizontal grid spacing of $0.1^{\circ} \times 0.1^{\circ}$. To allow comparison between station point data and EDGAR's gridded data, the "point-to-pixel comparison" approach [31] was used, whereby the value of the grid where the station point is in was extracted as station data. The number of active vehicles on road by state was obtained from the Road Transport Department of Malaysia [32].

\section{Results and Discussion}

\subsection{Overview of Ozone Distribution}

Kuala Lumpur, the capital city of Malaysia, and its surrounding area, the greater Klang Valley region, is a highly dense urban-commercial hub in Malaysia. Station S3 is located within the Klang Valley region and is close to an international shipping port. Station S2 is located north of Kuala Lumpur and the Klang Valley, while stations S1 and S4 are the locations furthest north and south, respectively, from Kuala Lumpur. Distribution of hourly $\mathrm{O}_{3}$ within the 20-year period for all four of these stations are presented in Figure 2. The mean values were within the range of 18-21 ppb, while the medians were in the range of 11-17 ppb. Stations S1 and S4 show higher median and mean values within the 20-year period compared to stations S2 and S3. The mirror image line on each side of the boxplot shows the distribution of the hourly data as a probability density plot. These so-called violin plots 
show some skewness in the distribution, as hourly values at S2 and S3 are more densely populated below the mean. S1 and S4 data also have a higher density of data distributed below the mean, but the probability density plot peak is broader at these two stations. Although the overall density and mean values indicate $\mathrm{O}_{3}$ concentrations extending to higher values at stations $\mathrm{S} 1$ and S4, neither stations recorded the highest observations of $\mathrm{O}_{3}$, and in fact, $\mathrm{S} 3$ recorded the highest hourly $\mathrm{O}_{3}$ value of $171 \mathrm{ppb}$, followed by S2 with 158 ppb.

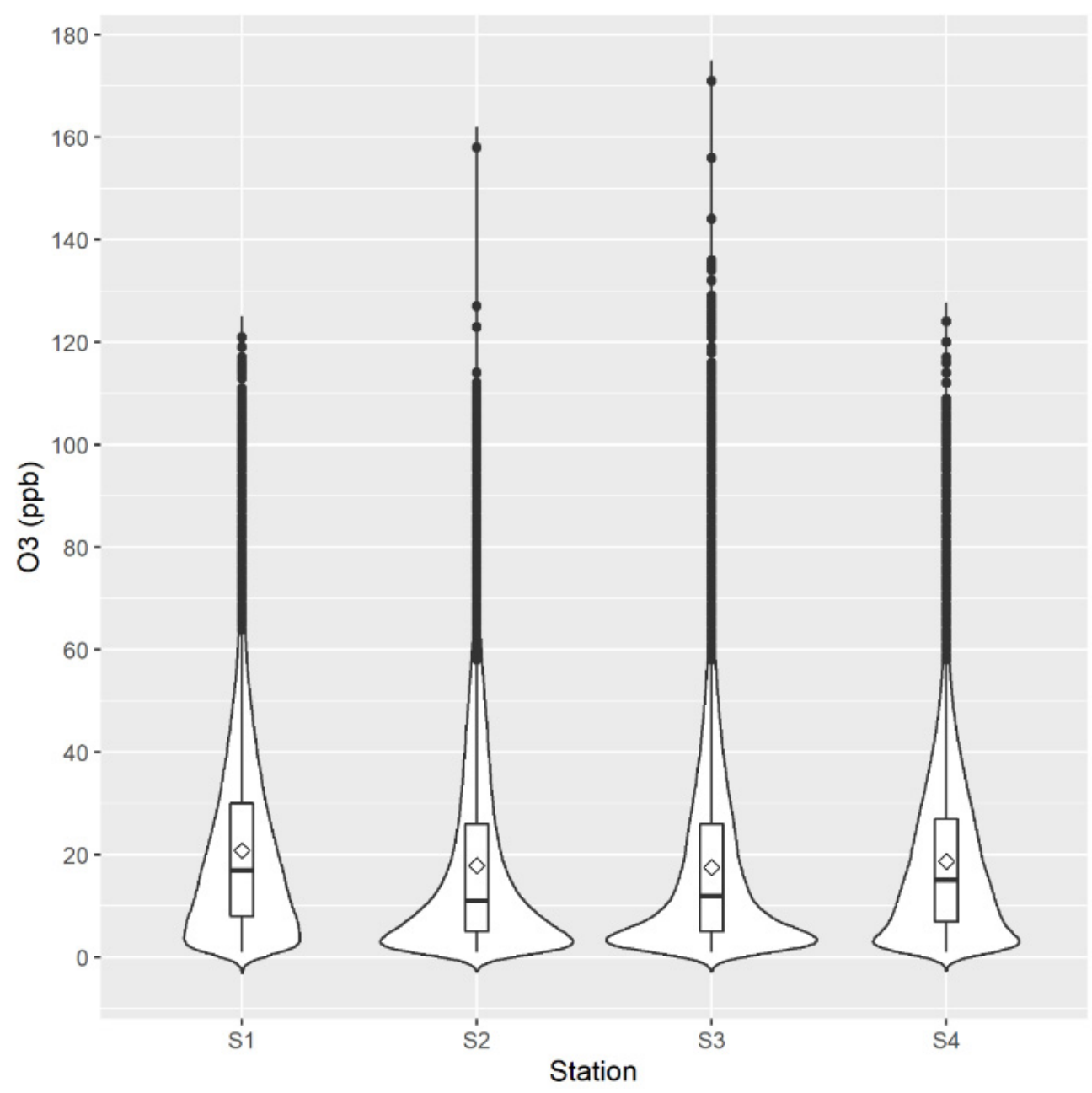

Figure 2. The violin plot provides a mirror image of the probability density function for each station. Box plots are also shown and mean values are labeled with diamond shaped markers.

The ambient air quality standard in Malaysia for hourly $\mathrm{O}_{3}$ is $100 \mathrm{ppb}$ [33]. Calculation of the fraction of hourly $\mathrm{O}_{3}$ values higher than this threshold shows that $\mathrm{S} 3$ records the highest non-compliance (Figure 3). The station is also the only location to record $\mathrm{O}_{3}$ non-compliance that is higher in the first decade of the study, while all the other locations show much higher occurrence of non-compliance to $\mathrm{O}_{3}$ in the latter decade (2007-2016). Time series plots of $\mathrm{O}_{3} \mathrm{Mmean}$ and $\mathrm{Mmax}$ are shown in Figure 4a,b, respectively. Most of the monthly mean $\mathrm{O}_{3}$ readings fall within the range of 10-25 ppb, while the monthly mean of daily maximum $\mathrm{O}_{3}$ was mostly within the 50-100 ppb range. Mmean at $\mathrm{S} 1$ records a much higher occurrence of Mmean falling within the upper range of 25-35 ppb $\mathrm{O}_{3}$. S3 records the highest occurrence of Mmax falling in the upper range of 100-150 ppb mostly in the earlier part of the decade (1997-2006), consistent with the results of hourly exceedance. 


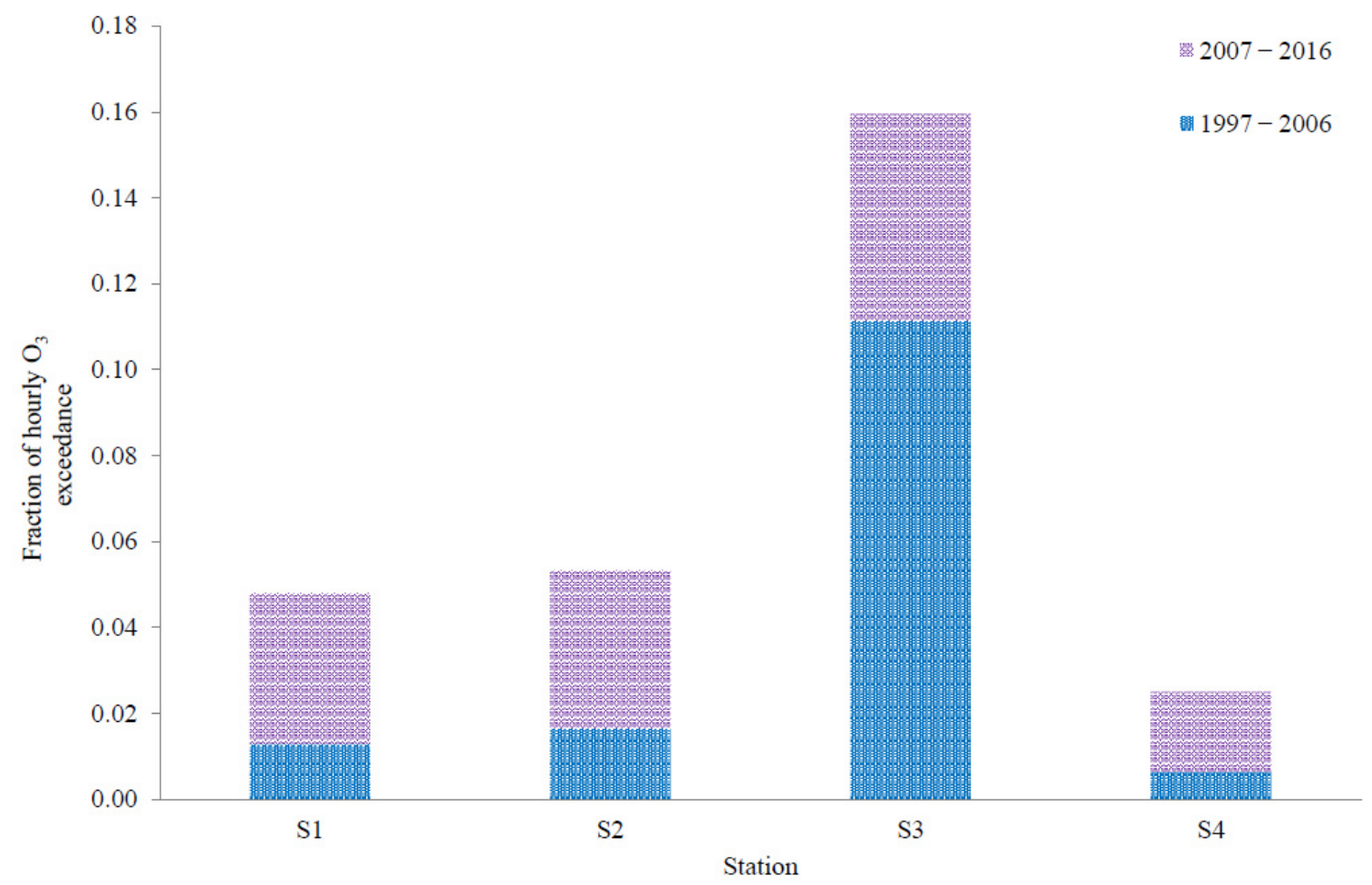

Figure 3. Fraction of hourly $\mathrm{O}_{3}$ concentrations that were higher than $100 \mathrm{ppb}$. The fraction is calculated from total hours of $\mathrm{O}_{3}$ exceedance divided by total available data for each station within the selected period.

(a) Mmean $\mathrm{O}_{3}$
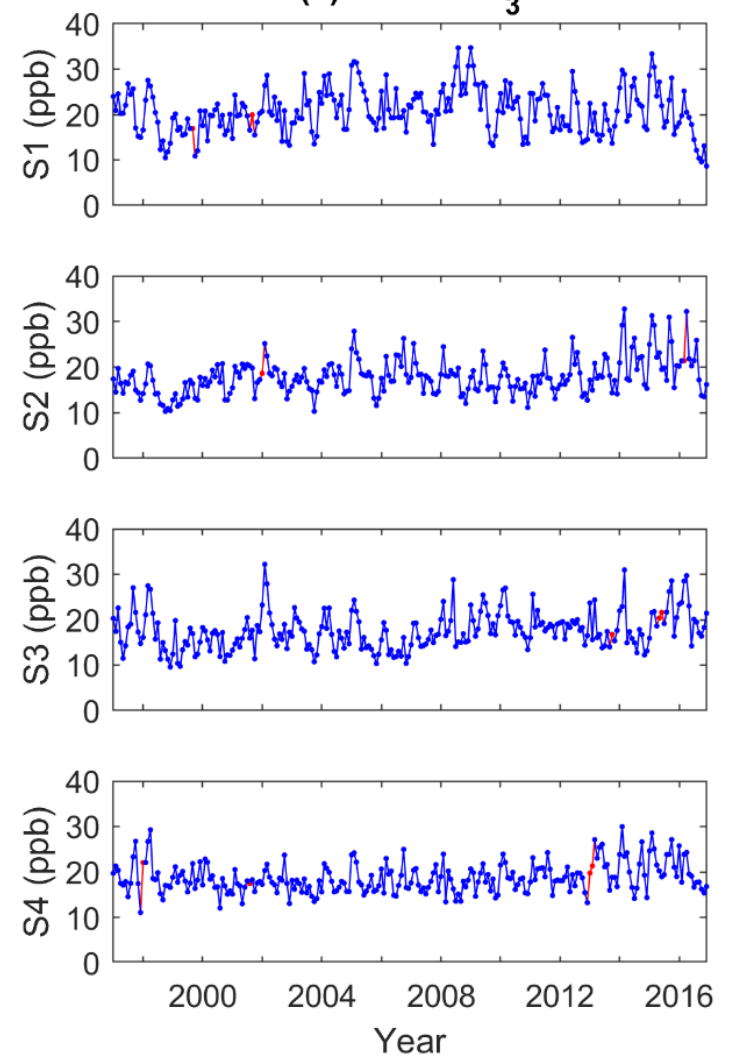

(b) $\mathrm{Mmax}_{3}$
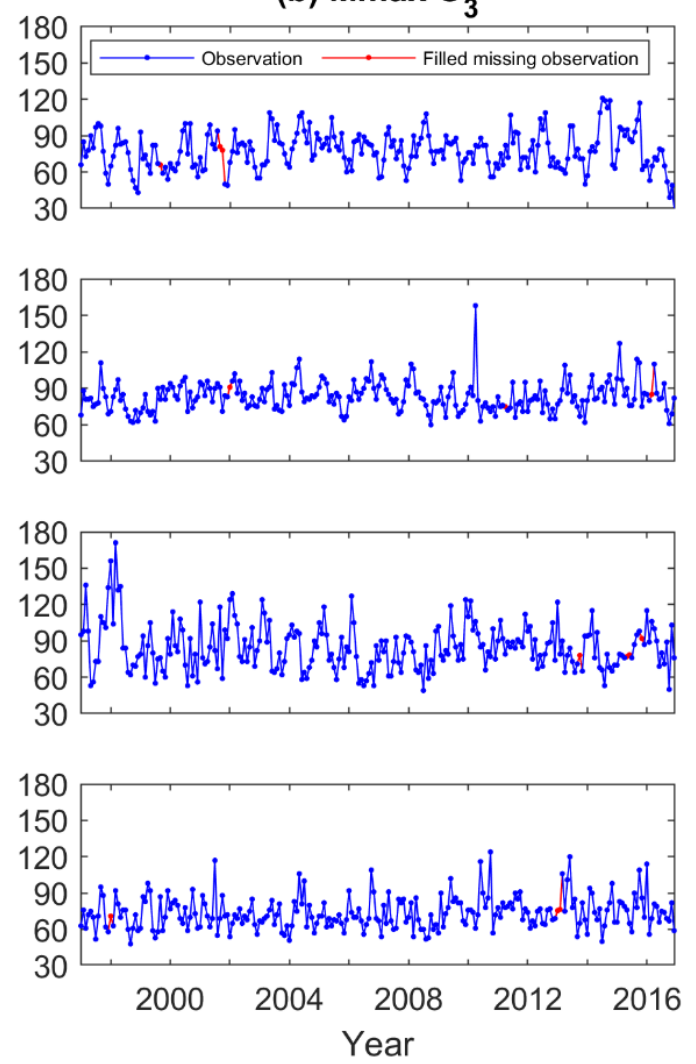

Figure 4. Time series (1997-2016) for (a) Monthly mean $\mathrm{O}_{3}$ (Mmean) and (b) Monthly mean of daily $\max \mathrm{O}_{3}$ (Mmax). 
Although the area around all four stations has been undergoing development within the 20-year period, the locales of stations S2 and, particularly, S3 were already more urbanized compared to S1 and S4 prior to 1997 (Supplementary Figure S1 provides satellite images for the stations during December 1996 and December 2016 for comparison). Station S3 has been shown to be among the locations that record very high $\mathrm{O}_{3}$ in Peninsular Malaysia $[5,6,34]$. Hence, the observed higher non-compliance and Mmax values at this location are largely to be expected. The hourly $\mathrm{O}_{3}$ distribution and Mmean values, however, indicate that the smaller and less densely urbanized areas such as around S1 are showing higher frequency of $\mathrm{O}_{3}$ concentrations falling in the upper range of the observations. To understand long term trends in $\mathrm{O}_{3}$ at the monitoring stations and its possible relation to other pollutants such as NO, deseasonalized trends (Section 3.2), correlation (Section 3.3), and diurnal composites (Section 3.4) are analyzed over the 20-year study period as well as for ten year intervals of 1997-2006 and 2007-2016.

\subsection{Trends in Ozone, Oxides of Nitrogen, and Selected Pollutant Ratios}

Deseasonalized trends for $\mathrm{O}_{3}$ and selected parameters are presented in Table 2. The Mmean $\mathrm{O}_{3}$ for the entire study period indicates significant increasing $\mathrm{O}_{3}$ at $\mathrm{S} 2, \mathrm{~S} 3$, and $\mathrm{S} 4$ at $p<0.05$, with rates of $0.19,0.21$, and $0.13 \mathrm{ppb} \mathrm{yr}^{-1}$, respectively. At $\mathrm{S} 1$, the trend is much lower, with an increase of only $0.09 \mathrm{ppb} \mathrm{yr}^{-1}(p<0.10)$. Overall, these results correspond to global trends, which show increasing surface and tropospheric $\mathrm{O}_{3}$ [24,35-40]. Decadal intervals, however, show that not all stations record significant increasing trends of $\mathrm{O}_{3}$. For the period between 1997 and 2006, only S1 and S2 recorded significant increases in $\mathrm{O}_{3}$ trends, with $\mathrm{S} 1$ recording the highest significant increase $\left(0.51 \mathrm{ppb} \mathrm{yr}^{-1}\right)$ between all stations for all periods studied. Between 2007 and 2016, S1 showed a decreasing $\mathrm{O}_{3}$ trend instead, at a rate of $-0.44 \mathrm{ppb} \mathrm{yr}^{-1}(p<0.05)$, which contributed to it recording the lowest increase in $\mathrm{O}_{3}$ over the entire 1997-2016 period. Stations S2, S3, and S4, meanwhile, showed significant increasing trends for the period between 2007 and 2016. S4 and S2 recorded the second and third highest rates of $\mathrm{O}_{3}$ increase with 0.44 and $0.42 \mathrm{ppb} \mathrm{yr}^{-1}(p<0.05)$, respectively, during this period. Although the 20-year trend showed increasing $\mathrm{O}_{3}$ at all stations, the $\mathrm{O}_{3}$ trend over the decadal period was less consistent between stations.

Table 2. Deseasonalized trends for monthly mean (Mmean) pollutant concentrations and monthly mean of daily maximum $\mathrm{O}_{3}\left(\mathrm{Mmax}_{3}\right)$ concentrations.

\begin{tabular}{|c|c|c|c|c|c|c|}
\hline & 1997-2006 & 2007-2016 & 1997-2016 & 1997-2006 & 2007-2016 & 1997-2016 \\
\hline & \multicolumn{3}{|c|}{ Deseasonalized Mmean $\mathrm{O}_{3}\left(\mathrm{ppb} \mathrm{yr}^{-1}\right)$} & \multicolumn{3}{|c|}{ Deseasonalized $\mathrm{Mmax}_{3} \mathrm{O}_{3}\left(\mathrm{ppb}_{\mathrm{yr}} \mathrm{r}^{-1}\right)$} \\
\hline S1 & 0.51 & -0.44 & 0.09 & 1.25 & -0.24 & 0.13 \\
\hline S2 & 0.36 & 0.42 & 0.19 & 1.06 & 0.15 & 0.03 \\
\hline S3 & -0.17 & 0.25 & 0.21 & -1.35 & 0.33 & -0.15 \\
\hline \multirow[t]{2}{*}{ S4 } & -0.09 & 0.44 & 0.13 & -0.21 & 0.38 & 0.3 \\
\hline & \multicolumn{3}{|c|}{ Deseasonalized Mmean NO (ppb yr $\left.{ }^{-1}\right)$} & \multicolumn{3}{|c|}{ Deseasonalized Mmean $\mathrm{NO}_{2}\left(\mathrm{ppb} \mathrm{yr}^{-1}\right)$} \\
\hline S1 & 0.30 & -0.18 & 0.12 & 0.20 & 0.01 & 0.16 \\
\hline S2 & 0.07 & -0.31 & -0.13 & 0.63 & -0.27 & 0.02 \\
\hline S3 & -1.33 & -0.62 & -0.98 & 0.06 & 0.10 & -0.01 \\
\hline \multirow[t]{2}{*}{ S4 } & 0.09 & 0.13 & 0.39 & 0.42 & 0.24 & 0.21 \\
\hline & \multicolumn{3}{|c|}{ Deseasonalized Mmean NOx (ppb yr $\left.{ }^{-1}\right)$} & \multicolumn{3}{|c|}{ Deseasonalized Mmean NO/NO$\left(\mathrm{yr}^{-1}\right)$} \\
\hline S1 & 0.43 & -0.23 & 0.24 & 0.01 & -0.01 & 0.00 \\
\hline S2 & 0.61 & -0.44 & -0.08 & -0.05 & -0.01 & -0.01 \\
\hline S3 & -1.27 & -0.47 & -0.99 & -0.07 & -0.02 & -0.04 \\
\hline \multirow[t]{2}{*}{ S4 } & 0.54 & 0.43 & 0.62 & -0.03 & -0.01 & 0.02 \\
\hline & \multicolumn{3}{|c|}{ Deseasonalized Mmean CO/NOx $\left(\mathrm{yr}^{-1}\right)$} & \multicolumn{3}{|c|}{ Deseasonalized Mmean $\mathrm{SO}_{2} / \mathrm{NOx}\left(\mathrm{yr}^{-1}\right)$} \\
\hline S1 & -4.30 & 3.95 & -1.45 & -0.07 & 0.00 & -0.02 \\
\hline S2 & -2.18 & 1.47 & -0.23 & -0.08 & 0.00 & -0.03 \\
\hline S3 & -0.99 & 0.46 & -0.13 & -0.02 & $0.00 *$ & -0.01 \\
\hline S4 & -2.14 & 0.34 & -0.91 & -0.05 & 0.00 & -0.02 \\
\hline
\end{tabular}

Note: Significant trends at $p<0.05$ in bold; Significant trend at $p<0.10$ in italics. ${ }^{*}$ trend value is $-0.0035 \mathrm{yr}^{-1}$. 
Mmean for oxides of nitrogen were also examined for comparison with $\mathrm{O}_{3}$ trends, since these are pollutants that play an important role in $\mathrm{O}_{3}$ photochemistry. Photochemical $\mathrm{O}_{3}$ formation involves a two-step process involving the dissociation of $\mathrm{NO}_{2}$ in the presence of sunlight $[10,12]$ :

$$
\mathrm{NO}_{2}+h v \rightarrow \mathrm{NO}+\mathrm{O}
$$

and the reaction of the oxygen atom with oxygen molecules in the presence of a third body $(\mathrm{M})$ :

$$
\mathrm{O}+\mathrm{O}_{2} \stackrel{\mathrm{M}}{\rightarrow} \mathrm{O}_{3}
$$

However, the $\mathrm{NO}$ from Equation (1) can rapidly react with the $\mathrm{O}_{3}$, forming $\mathrm{NO}_{2}$ :

$$
\mathrm{NO}+\mathrm{O}_{3} \rightarrow \mathrm{NO}_{2}+\mathrm{O}_{2}
$$

Hence, typically, $\mathrm{O}_{3}$ peaks do not occur until $\mathrm{NO}$ concentrations have fallen, as $\mathrm{NO}$ can titrate $\mathrm{O}_{3}$. The NO and NOx trends over 1997-2016 both show negative trends for S2 and S3 and a non-significant trend for $\mathrm{NO}_{2}$. $\mathrm{S} 4$ shows significant increase in $\mathrm{NO}, \mathrm{NO}_{2}$ and $\mathrm{NOx}$ for all three periods studied. These trends do not consistently correspond to the $\mathrm{Mmean}_{3}$ trends either directly or inversely, and this is expected, since $\mathrm{O}_{3}$ concentrations in ambient air are not solely influenced by $\mathrm{O}_{3}$ photochemistry. Comparing the differences in Mmean $\mathrm{O}_{3}$ trends between some of the stations, such as S3 and S4 or S2 and S3 for the period of 1997-2016, gives better insight into the ozone-precursor behavior. The difference in Mmean $\mathrm{O}_{3}$ trends for the 1997-2016 period is relatively high between S3 and S4, with a value of $0.08 \mathrm{ppb} \mathrm{yr}^{-1}$. However, a smaller difference of $0.02 \mathrm{ppb} \mathrm{yr}^{-1}$ is recorded between S2 and S3. Similarly, S1 and S4 pairing recorded a difference of only $0.04 \mathrm{ppb} \mathrm{yr}^{-1}$ between them. The NO and $\mathrm{NO}_{\mathrm{x}}$ trends show that it is only S2 and S3 that record decreasing levels in these species, while S1 and $\mathrm{S} 4$ showed increasing trends in both $\mathrm{NO}$ and NOx level. The $\mathrm{NO}_{2}$ trends for $\mathrm{S} 1$ and $\mathrm{S} 4$ both show significant increase within a 20-year period at $p<0.05$, while both S2 and S3 have non-significant trends, even at $p<0.10$. The distinctive pairing reflects combination of locations that were more urbanized (S2 and S3) or less urbanized (S1 and S4) prior to 1997.

Trends of $\mathrm{Mmax}_{3}$ were more varied between stations and between the selected periods compared to Mmean trends. Only S4 shows a significant positive trend in $\mathrm{Mmax}_{3}$, despite the increase in $\mathrm{O}_{3}$ exceedance in the period between 2007-2016 compared to 1997-2006 at S1, S2, and S4. The Mmax $\mathrm{O}_{3}$ trends were only significant at $\mathrm{S} 4$, with a rate of $0.3 \mathrm{ppb} \mathrm{yr}^{-1}$ for the period between 1997 and 2016. Station $\mathrm{S} 3$ recorded a non-significant decreasing $\mathrm{Mmax}_{3} \mathrm{O}_{3}$ trend between the 1997 and 2016 period, despite recording the highest Mmean trends for the same period. For the first decadal interval of 1997-2006, S3 showed a significant decrease in $\mathrm{O}_{3}$ maxima at a rate of $-1.35 \mathrm{ppb} \mathrm{yr}^{-1}$, while S1 and S2 recorded significant increasing trends. In the latter interval of 2007-2016, none of the stations recorded significant trends. Given that $\mathrm{O}_{3}$ maxima are more likely linked to localized influence rather than a combination of regional and local precursor distribution and meteorology [41], fewer significant trends in $\mathrm{O}_{3}$ maxima in comparison to mean $\mathrm{O}_{3}$ concentrations at the stations can be expected. Although there is an overall global increase in $\mathrm{O}_{3}$ and regional photochemical production is an important source of $\mathrm{O}_{3}$ in decadal time scales [42], local emission profiles or saturation of precursor species are sufficiently dominant to influence $\mathrm{O}_{3}$ trends. It would appear that peak values of $\mathrm{O}_{3}$ are less dependent upon an expected increase in emission from urban-commercial expansion, but instead reflect a unique chemistry-meteorology combination that varies on a day to day basis.

Ratios of $\mathrm{NO} / \mathrm{NO}_{2}, \mathrm{CO} / \mathrm{NOx}$, and $\mathrm{SO}_{2} / \mathrm{NOx}$ were also analyzed, as these can provide some indications as to whether the location is influenced by mobile or point sources. Given that mobile sources typically have higher emissions of $\mathrm{CO}$ and $\mathrm{NOx}$, while point sources have higher $\mathrm{SO}_{2}$ and $\mathrm{NO}_{\mathrm{x}}$ emissions, high $\mathrm{SO}_{2} / \mathrm{NOx}$ paired with low $\mathrm{CO} / \mathrm{NOx}$ ratios, for example, could indicate point sources [43-45]. Increasing $\mathrm{NO} / \mathrm{NO}_{2}$ ratios indicate locations closer to traffic emissions [46,47]. The trend for the ratios shows a decrease for all combinations at S2 and S3, despite these stations 
showing urban expansion, which is expected to cause an increase in traffic volume (Figure 5a). Figure $5 a$ does, however, highlight the more urbanized profile of stations S2 and S3, with vehicular counts that are a magnitude higher than stations S1 and S4. The total emissions derived from the EDGAR database (Figure $5 \mathrm{~b}-\mathrm{d}$ ) also indicate that $\mathrm{S} 3$ has the highest emissions from all sources due to its high population, traffic density, and urban-commercial expansion. It also shows that $\mathrm{S} 1$ and $\mathrm{S} 2$ have a more similar emission profile to each other, unlike the pairing for the number of active vehicles on the road (Figure 5a).

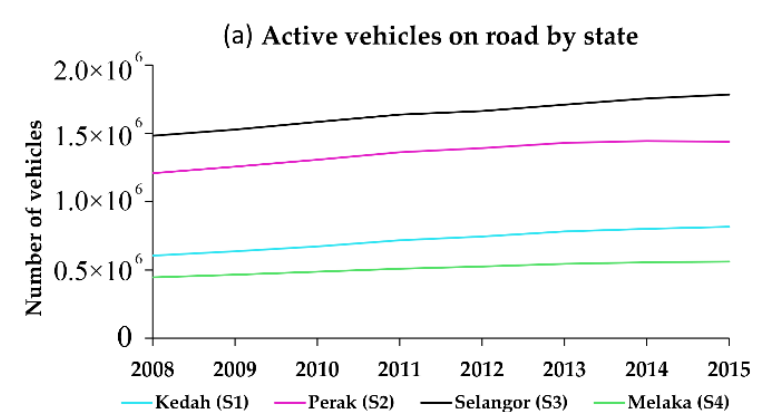

(c) $\mathrm{CO}$ emissions (all sources)

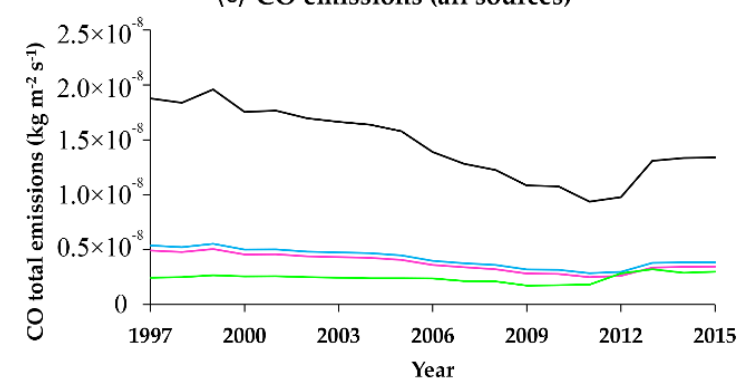

(b) NOx emissions (all sources)

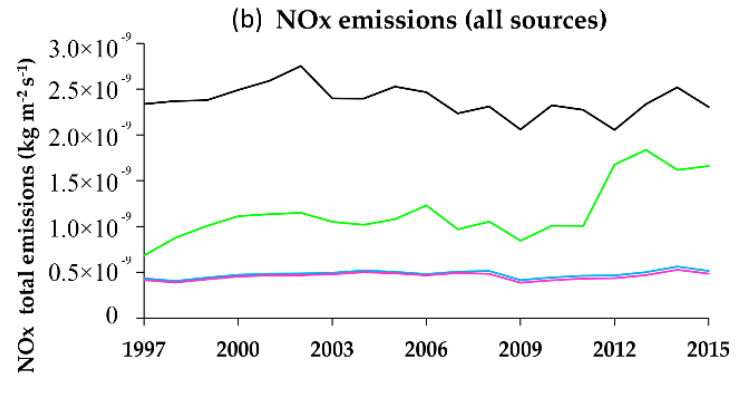

(d) $\mathrm{SO}_{2}$ emissions (all sources) $\quad-\mathrm{S} 1$

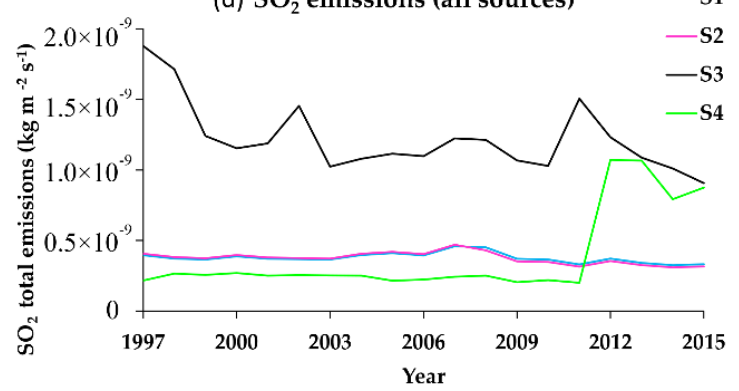

Figure 5. Time series of total active vehicle count by state for the period 2008-2015 (a) and total emissions (all sources) for NOx, CO and SO2 for the period 1997-2015 (a-c).

\subsection{Correlation of Monthly Mean Ozone with Selected Parameters}

The correlation analysis is carried out on monthly means to smooth out meteorologically influenced diurnal and intra-seasonal signals that could influence $\mathrm{O}_{3}$ behavior. However, $\mathrm{O}_{3}$ and other pollutant concentrations are also influenced by emissions, planetary boundary layer height and long-distance transport, in addition to chemistry and meteorology in varying degrees, depending on the time scale chosen [39,48-51]. All of this contributes to the potentially non-linear relationship between $\mathrm{O}_{3}$ and other pollutants. Hence, a non-parametric method was selected, as the focus is on identifying potential relationship between $\mathrm{O}_{3}$ and the selected pollutants over the period of study that may provide insight into relative behavior of other pollutants in relation to $\mathrm{O}_{3}$.

The correlation analysis results between $\mathrm{O}_{3}$ and selected parameters over the individual decades are shown in Table 3. $\mathrm{NO}$ and $\mathrm{NO}_{2}$ showed negative and positive correlation with $\mathrm{O}_{3}$, respectively, at all stations with the exception of negative $\mathrm{NO}_{2}$ correlation with $\mathrm{O}_{3}$ at $\mathrm{S} 4$ for the period between 1997 and 2006. Additionally, data from both $\mathrm{S} 3$ and $\mathrm{S} 4$ showed insignificant correlation between $\mathrm{O}_{3}$ and $\mathrm{NO}$ at selected durations. Figure 6 presents time series for $\mathrm{NO}, \mathrm{NO}_{2}, \mathrm{CO}$, and $\mathrm{SO}_{2}$, in which $\mathrm{S} 3$ records the overall highest pollutant concentrations, while $\mathrm{S} 4$ is the only station to show increasing NO in the latter decade. NOx also showed no significant relationship with $\mathrm{O}_{3}$, except for $\mathrm{S} 4$ in the first decade and $\mathrm{S} 3$ for the total study duration. With the exception of $\mathrm{NO} / \mathrm{NO}_{2}$ ratios, none of the parameters showed a similar significant relationship between stations when the results were compared between the decadal and total study duration. These results are similar to the trend results, supporting our finding that there is no clear link between ambient $\mathrm{O}_{3}$ and oxides of nitrogen observations when the results are seen individually. 


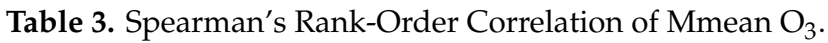

\begin{tabular}{|c|c|c|c|c|c|c|c|}
\hline & & NO & $\mathrm{NO}_{2}$ & NOx & $\mathrm{NO} / \mathrm{NO}_{2}$ & CO/NOx & $\mathrm{SO}_{2} / \mathrm{NOx}$ \\
\hline \multicolumn{8}{|c|}{ 1997-2006 } \\
\hline S1 & \multirow{4}{*}{$\mathrm{O}_{3}$} & -0.28 & 0.27 & -0.17 & -0.5 & 0.12 & -0.04 \\
\hline S2 & & -0.46 & 0.64 & 0.33 & -0.69 & -0.19 & -0.34 \\
\hline S3 & & -0.17 & 0.43 & 0.04 & -0.34 & 0.44 & 0.22 \\
\hline S4 & & -0.41 & -0.07 & -0.25 & -0.22 & 0.26 & 0.29 \\
\hline \multicolumn{8}{|c|}{ 2007-2016 } \\
\hline S1 & \multirow{4}{*}{$\mathrm{O}_{3}$} & -0.23 & 0.25 & 0.02 & -0.39 & -0.06 & 0.12 \\
\hline S2 & & -0.55 & 0.38 & 0.01 & -0.67 & 0.09 & -0.07 \\
\hline S3 & & -0.37 & 0.36 & -0.05 & -0.52 & 0.18 & 0.07 \\
\hline S4 & & -0.16 & 0.29 & 0.08 & -0.4 & 0.18 & 0.02 \\
\hline \multicolumn{8}{|c|}{ 1997-2016 } \\
\hline S1 & \multirow{4}{*}{$\mathrm{O}_{3}$} & -0.18 & 0.27 & -0.01 & -0.43 & -0.03 & -0.04 \\
\hline S2 & & -0.51 & 0.5 & 0.11 & -0.69 & -0.06 & -0.24 \\
\hline S3 & & -0.38 & 0.36 & -0.18 & -0.50 & 0.29 & -0.04 \\
\hline S4 & & -0.04 & 0.18 & 0.04 & -0.14 & 0.12 & 0.01 \\
\hline
\end{tabular}

Note: Significant correlation at $p<0.05$ in bold.

(a) Mmean NO

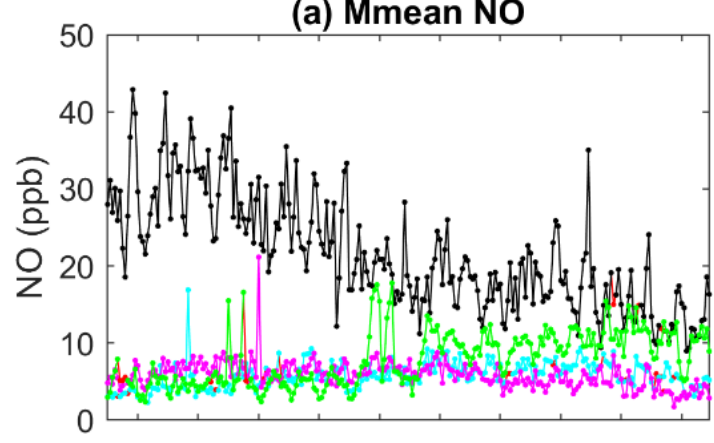

(c) Mmean CO

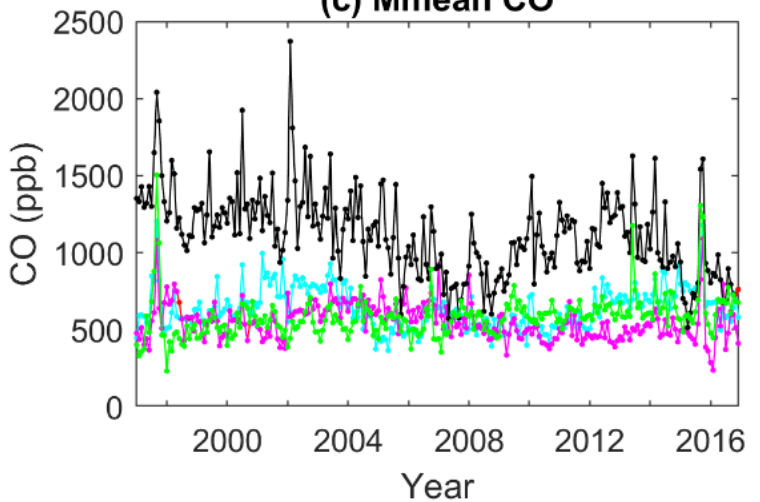

(b) Mmean $\mathrm{NO}_{2}$

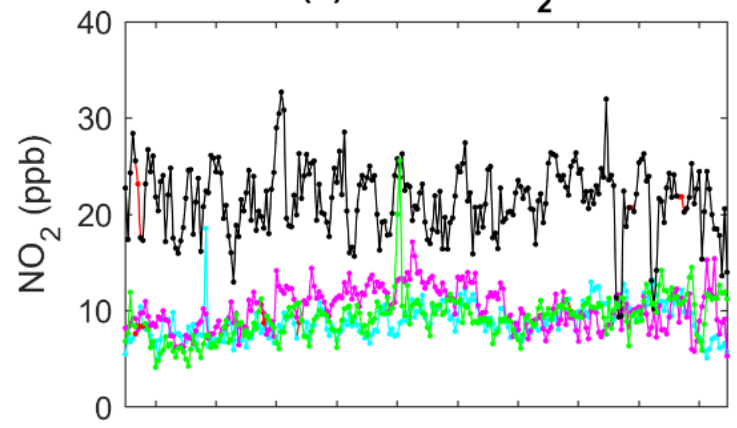

(d) Mmean $\mathrm{SO}_{2}$

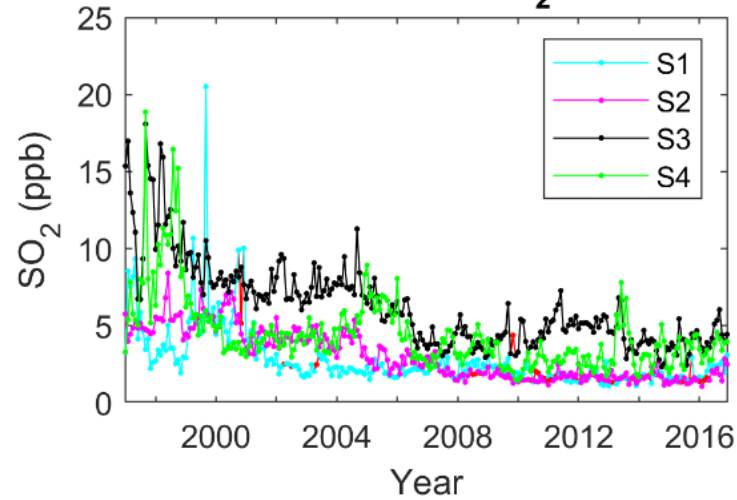

Figure 6. Time series of Mmean for $\mathrm{NO}(\mathbf{a}), \mathrm{NO}_{2}(\mathbf{b}), \mathrm{CO}(\mathbf{c})$, and $\mathrm{SO}_{2}(\mathbf{d})$. Data points in red are missing observations that have been filled with computed values.

All the stations showed a significant negative relationship with $\mathrm{NO} / \mathrm{NO}_{2}$ ratios, that is, less $\mathrm{O}_{3}$ at higher NO levels. S2, for example, consistently obtained coefficient values above 0.5 within all study periods for $\mathrm{O}_{3}$ relationship with $\mathrm{NO} / \mathrm{NO}_{2}$ ratios. $\mathrm{O}_{3}$ relationship with $\mathrm{NO}$ and $\mathrm{NO}_{2}$ (Equations (1)-(3)) at steady state can be represented by $\mathrm{O}_{3}=j_{\mathrm{NO} 2}\left[\mathrm{NO}_{2}\right] / k_{1}[\mathrm{NO}]$, where $j_{\mathrm{NO} 2}$ is the photolysis rate for $\mathrm{NO}_{2}$ and $k_{1}$ is the rate constant for the reaction between $\mathrm{NO}$ and $\mathrm{O}_{3}$ [11]. Hence, the results are in 
fact more consistent with control of monthly mean $\mathrm{O}_{3}$ levels by increasing titration of $\mathrm{O}_{3}$ by NO into $\mathrm{NO}_{2}$. The $\mathrm{S} 1$ station had shown a large difference in $\mathrm{O}_{3}$ trends between the first decade and the last decade. However, results of the correlation analysis do not show large differences in the $\mathrm{NO}, \mathrm{NO}_{2}$, and $\mathrm{NO} / \mathrm{NO}_{2}$ relationship with $\mathrm{O}_{3}$ between the decades. The only observable difference is in the trend of NO itself (Table 2), where NO is increasing in the first decade and decreasing in the next. Without additional information on other precursor species, such as VOC and localized emission profile, it is not possible to determine with certainty if $\mathrm{O}_{3}$ titration caused the significant change in $\mathrm{O}_{3}$ in the last few years of the latter decade. The $\mathrm{CO} / \mathrm{NOx}$ and $\mathrm{SO}_{2} / \mathrm{NOx}$ ratios only showed a significant relationship with $\mathrm{O}_{3}$ at $\mathrm{S} 2, \mathrm{~S} 3$, and $\mathrm{S} 4$ for the first decade and were not significant during other periods. The lack of consistency in $\mathrm{O}_{3}$ and pollutant ratio relationship is also reflected in the differing trends of $\mathrm{O}_{3}$ and pollutant ratio between stations (Table 2).

\subsection{Diurnal Variation Composites}

In order to determine if there are any changes in the diurnal profile between the decadal intervals at each station, a composite of hourly data was plotted for the period of 1997-2006 and 2007-2016 (Figure 7). The difference between the two (the latter decade minus the earlier decade) was also plotted. The decadal diurnal composites show a change in magnitude of pollutant concentration but no temporal shift (peaks occurring at similar times). $\mathrm{O}_{3}$ shows an increase at all stations, with $\mathrm{S} 3$ showing the largest difference between the decades overall. NO at S2 shows a relatively small decrease in the latter decade compared to S3 that records the largest decrease in NO in the same period. S1 and $\mathrm{S} 4$ show an increase in $\mathrm{NO}$, but with an almost similar magnitude of change to $\mathrm{S} 2$ and $\mathrm{S} 3$, respectively. $\mathrm{NO}_{2}$ shows a much smaller decadal difference between all the stations compared to $\mathrm{NO}$ and hence, the $\mathrm{NO} / \mathrm{NO}_{2}$ differences are primarily influenced by the change in $\mathrm{NO}$ rather than $\mathrm{NO}_{2}$. The change in $\mathrm{NO}$, either an increase or decrease, makes only a relatively small difference to $\mathrm{NO}_{2}$ levels. At $\mathrm{S} 3$, which is highly urbanized, the observations suggest that $\mathrm{NO}$ to $\mathrm{NO}_{2}$ conversion (Equation (3)) and $\mathrm{O}_{3}$ levels are controlled by local $\mathrm{NO}$ emissions. At $\mathrm{S} 3, \mathrm{O}_{3}$ increases in the latter decade, while $\mathrm{NO}$ decreases over the same period. This is consistent with $\mathrm{S} 3$ being situated close to NO emission sources and strong titration of $\mathrm{O}_{3}$ by $\mathrm{NO}$. However, $\mathrm{NO}$ to $\mathrm{NO}_{2}$ conversion can also be affected by formation of $\mathrm{NO}_{2}$ via the VOC pathway. In contrast to station $\mathrm{S} 3$, station $\mathrm{S} 4$ shows increase in $\mathrm{O}_{3}$ and increase in $\mathrm{NO}$ between the decades, which is consistent with increased production of $\mathrm{NO}_{2}$ via reactions of peroxyl radicals with $\mathrm{NO}$, e.g., $\mathrm{HO}_{2} / \mathrm{RO}_{2}+\mathrm{NO} \rightarrow \mathrm{OH} / \mathrm{RO}+\mathrm{NO}_{2}$ [10,52]. Different stations appear to show different NOx sensitivity and presumably, VOC sensitivity. Having stations with different NOx and VOC sensitivities poses additional challenge in air pollution mitigation as reduction in NOx, for example, could actually result in increasing $\mathrm{O}_{3}$ at some locations such as $\mathrm{S} 3$. 

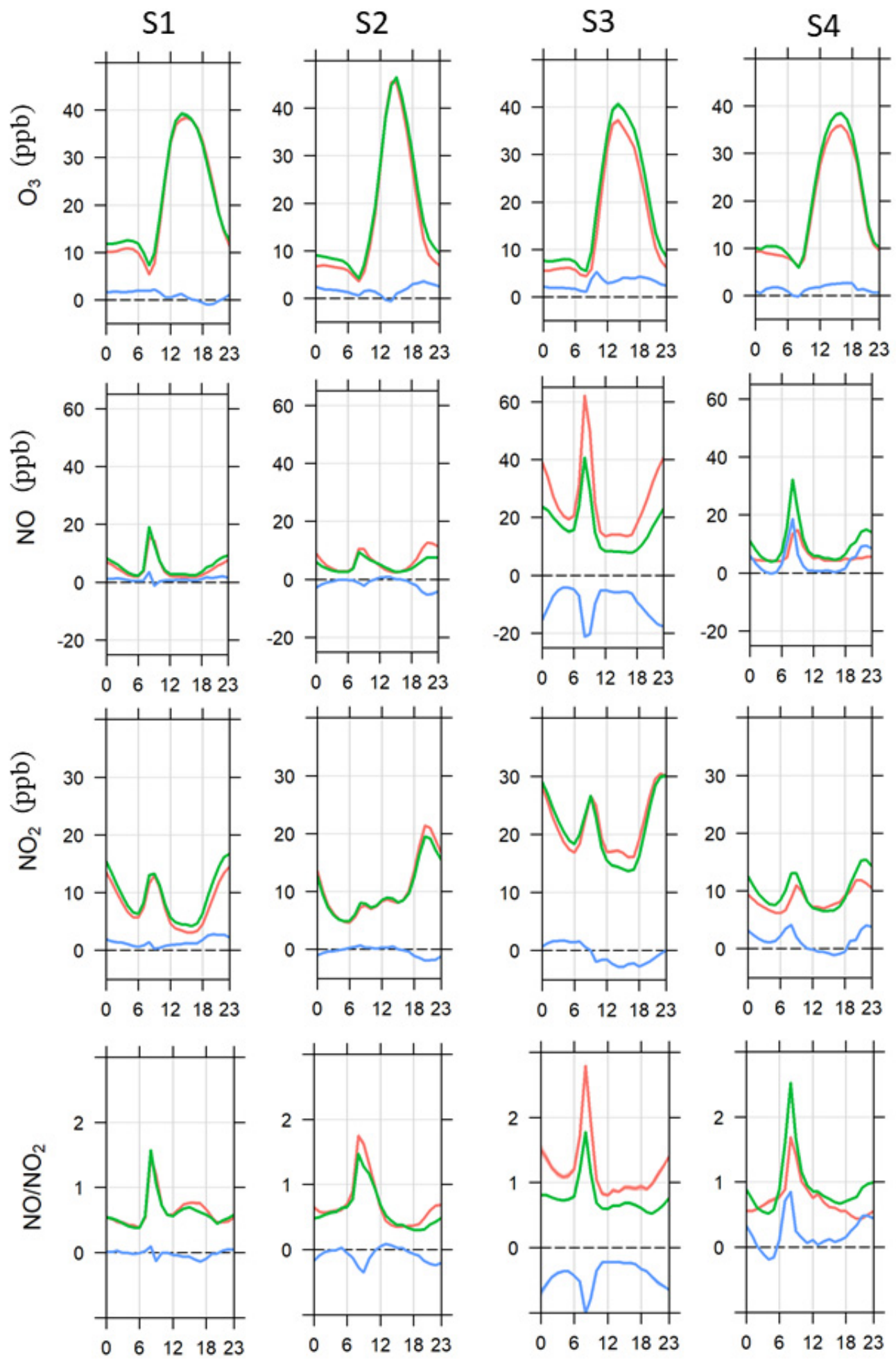

hour

hour

hour

hour $1997-2006$
$2007-2016$

(2007 -2016) - (1997-2006)

Figure 7. Composite of diurnal plots for $\mathrm{O}_{3}, \mathrm{NO}, \mathrm{NO}_{2}$, and $\mathrm{NO} / \mathrm{NO}_{2}$. 


\section{Conclusions}

The trends in deseasonalized $\mathrm{Mmean}_{3}$ show that there has been an increase in $\mathrm{O}_{3}$ within the 20-year period at all the stations. Station S3, which is the most densely populated and urbanized location, recorded the highest rate of increase $\left(0.21 \mathrm{ppb} \mathrm{yr}^{-1}, p<0.05\right)$. This is followed by stations $\mathrm{S} 2$ and $\mathrm{S} 4$ at rates of 0.19 and $0.13 \mathrm{ppb} \mathrm{yr}^{-1}(p<0.05)$, respectively. The lowest increase in $\mathrm{O}_{3}$ was recorded at $\mathrm{S} 1$, with a rate of $0.09 \mathrm{ppb} \mathrm{yr}^{-1}(p<0.10)$. Decadal intervals showed a more varied pattern in $\mathrm{O}_{3}$ trends. In the first decade (1997-2006), $\mathrm{S} 1$ showed the highest recorded significant increase in $\mathrm{O}_{3}\left(0.51 \mathrm{ppb} \mathrm{yr}^{-1}\right)$, but it then recorded the largest significant decrease in $\mathrm{O}_{3}$ in the 2007-2016 period $\left(-0.44 \mathrm{ppb} \mathrm{yr}^{-1}\right)$. S2 and S4 showed the largest increment over the latter decade (2007-2016), with rates of 0.42 and $0.44 \mathrm{ppb} \mathrm{yr}^{-1}$, respectively. Both the NO and NOx trends were negative at S2 and S3, while S1 and S4 showed positive trends $(p<0.05)$ during the 1997-2016 period. Mmax $\mathrm{O}_{3}$ trends were only significant at $\mathrm{S} 4$ within the 20 -year period $\left(0.3 \mathrm{ppb} \mathrm{yr}^{-1}\right)$. Correlation analysis showed that the $\mathrm{NO} / \mathrm{NO}_{2}$ ratio more consistently produced a significant negative correlation with Mmean $\mathrm{O}_{3}$ irrespective of the period of analysis, which corresponds to $\mathrm{O}_{3}$ control by photostationary state reactions. The diurnal composites for decadal changes suggest that the stations may have different NOx and VOC sensitivities. However, further analysis on $\mathrm{O}_{3}$ sensitivity to NOx and VOC is required for conclusive evidence on the potential saturation of NOx or VOC at the locations.

Supplementary Materials: The following are available online at http://www.mdpi.com/2073-4433/11/7/755/s1, Figure S1: Satellite image of station locations in December 1996 and December 2016.

Author Contributions: Conceptualization, F.A.; Data curation, F.A., P.T.G., C.J.X.; Formal analysis, F.A.; writing—original draft preparation, F.A.; writing—review and editing, F.A., P.T.G., M.T.L., L.J., C.J.X.; visualization, F.A., C.J.X.; funding acquisition, F.A. All authors have read and agreed to the published version of the manuscript.

Funding: This research was funded by Universiti Kebangsaan Malaysia, Geran Galakan Penyelidik Muda GGPM-2017-083.

Acknowledgments: The authors would like to thank the DoE Malaysia for the provision of air quality data used in this study.

Conflicts of Interest: The authors declare no conflict of interest. The funders had no role in the design of the study; in the collection, analyses, or interpretation of data; in the writing of the manuscript, or in the decision to publish the results.

\section{References}

1. Fleming, Z.L.; Doherty, R.; von Schneidemesser, E.; Malley, C.; Cooper, O.; Pinto, J.; Colette, A.; Xu, X.; Simpson, D.; Schultz, M.; et al. Global Ozone Distribution relevant to Human Health: Metrics and present day levels from the Tropospheric Ozone Assessment Report (TOAR). Elem. Sci. Anth. 2018, 6. [CrossRef]

2. Pleijel, H.; Broberg, M.C.; Uddling, J.; Mills, G. Current surface ozone concentrations significantly decrease wheat growth, yield and quality. Sci. Total Environ. 2018, 613, 687-692. [CrossRef] [PubMed]

3. Ishii, S.; Bell, J.; Marshall, F. Phytotoxic risk assessment of ambient air pollution on agricultural crops in Selangor State, Malaysia. Environ. Pollut. 2007, 150, 267-279. [CrossRef]

4. Wan Mahiyuddin, W.R.; Sahani, M.; Aripin, R.; Latif, M.T.; Thach, T.-Q.; Wong, C.-M. Short-term effects of daily air pollution on mortality. Atmos. Environ. 2013, 65, 69-79. [CrossRef]

5. Latif, M.T.; Huey, L.S.; Juneng, L. Variations of surface ozone concentration across the Klang Valley, Malaysia. Atmos. Environ. 2012, 61, 434-445. [CrossRef]

6. Mohtar, A.A.A.; Latif, M.T.; Baharudin, N.H.; Ahamad, F.; Chung, J.X.; Othman, M.; Juneng, L. Variation of major air pollutants in different seasonal conditions in an urban environment in Malaysia. Geosci. Lett. 2018, 5, 21. [CrossRef]

7. Azmi, S.Z.; Latif, M.T.; Ismail, A.S.; Juneng, L.; Jemain, A.A. Trend and status of air quality at three different monitoring stations in the Klang Valley, Malaysia. Air Qual. Atmos. Health 2010, 3, 53-64. [CrossRef]

8. Latif, M.T.; Othman, M.; Idris, N.; Juneng, L.; Abdullah, A.M.; Hamzah, W.P.; Khan, M.F.; Nik Sulaiman, N.M.; Jewaratnam, J; Aghamohammadi, N.; et al. Impact of regional haze towards air quality in Malaysia: A review. Atmos. Environ. 2018, 177, 28-44. [CrossRef] 
9. Keywood, M.; Ayers, G.; Gras, J.; Boers, C. Haze in the Klang valley of Malaysia. Atmos. Chem. Phys. Discuss. 2003, 3, 615-653. [CrossRef]

10. Finlayson-Pitts, B.J.; Pitts, J.N. Chemistry of the Upper and Lower Atmosphere: Theory, Experiments and Applications; Academic Press: San Diego, CA, USA, 2000.

11. Seinfeld, J.H.; Pandis, S.N. Atmospheric Chemistry and Physics: From Air Pollution to Climate Change, 2nd ed.; JohnWiley and Sons, Inc.: NewYork, NY, USA, 2006.

12. Sillman, S. The relation between ozone, NOx and hydrocarbons in urban and polluted rural environments. Atmos. Environ. 1999, 33, 1821-1845. [CrossRef]

13. Chameides, W.; Fehsenfeld, F.; Rodgers, M.; Cardelino, C.; Martinez, J.; Parrish, D.; Lonneman, W.; Lawson, D.; Rasmussen, R.; Zimmerman, P. Ozone precursor relationships in the ambient atmosphere. J. Geophys. Res. 1992, 97, 6037-6055. [CrossRef]

14. Lu, X.; Zhang, L.; Chen, Y.; Zhou, M.; Zheng, B.; Li, K.; Liu, Y.; Lin, J.; Fu, T.M.; Zhang, Q. Exploring $2016-2017$ surface ozone pollution over China: Source contributions and meteorological influences. Atmos. Chem. Phys. 2019, 19, 8339-8361. [CrossRef]

15. Ellis, A.W.; Hildebrandt, M.L.; Thomas, W.M.; Fernando, H. Analysis of the climatic mechanisms contributing to the summertime transport of lower atmospheric ozone across metropolitan Phoenix, Arizona, USA. Clim. Res. 2000, 15, 13-31. [CrossRef]

16. Banan, N.; Latif, M.T.; Juneng, L.; Ahamad, F. Characteristics of Surface Ozone Concentrations at Stations with Different Backgrounds in the Malaysian Peninsula. Aerosol Air Qual. Res. 2013, 13, 1090-1106. [CrossRef]

17. Toh, Y.Y.; Lim, S.F.; Von Glasow, R. The influence of meteorological factors and biomass burning on surface ozone concentrations at Tanah Rata, Malaysia. Atmos. Environ. 2013, 70, 435-446. [CrossRef]

18. Ismail, M.; Suroto, A.; Ismail, N.A. Time series analysis of surface ozone monitoring records in Kemaman, Malaysia. In Air Pollution-A Comprehensive Perspective; Haryanto, B., Ed.; InTechOpen: London, UK, 2012. [CrossRef]

19. Ashfold, M.; Latif, M.; Samah, A.; Mead, M.I.; Harris, N.R. Influence of Northeast Monsoon cold surges on air quality in Southeast Asia. Atmos. Environ. 2017, 166, 498-509. [CrossRef]

20. Awang, N.R.; Ramli, N.A.; Shith, S.; Zainordin, N.S.; Manogaran, H. Transformational characteristics of ground-level ozone during high particulate events in urban area of Malaysia. Air Qual. Atmos. Health 2018, 11, 715-727. [CrossRef]

21. Awang, N.R.; Ramli, N.A.; Shith, S.; Md Yusof, N.F.F.; Zainordin, N.S.; Sansuddin, N.; Ghazali, N.A. Time effects of high particulate events on the critical conversion point of ground-level ozone. Atmos. Environ. 2018, 187, 328-334. [CrossRef]

22. Latif, M.T.; Dominick, D.; Ahamad, F.; Khan, M.F.; Juneng, L.; Hamzah, F.M.; Nadzir, M.S.M. Long term assessment of air quality from a background station on the Malaysian Peninsula. Sci. Total Environ. 2014, 482, 336-348. [CrossRef]

23. Jamaluddin, A.F.; Tangang, F.; Chung, J.X.; Juneng, L.; Sasaki, H.; Takayabu, I. Investigating the mechanisms of diurnal rainfall variability over Peninsular Malaysia using the non-hydrostatic regional climate model. Meteorol. Atmos. Phys. 2018, 130, 611-633. [CrossRef]

24. Wang, T.; Dai, J.; Lam, K.S.; Nan Poon, C.; Brasseur, G.P. Twenty-Five Years of Lower Tropospheric Ozone Observations in Tropical East Asia: The Influence of Emissions and Weather Patterns. Geophys. Res. Lett. 2019, 46, 11463-11470. [CrossRef]

25. Fernandes, R.G.; Leblanc, S. Parametric (modified least squares) and non-parametric (Theil-Sen) linear regressions for predicting biophysical parameters in the presence of measurement errors. Remote Sens. Environ. 2005, 95, 303-316. [CrossRef]

26. Carslaw, D.C.; Ropkins, K. openair-An R package for air quality data analysis. Environ. Modell. Softw. 2012, 27-28, 52-61. [CrossRef]

27. Cleveland, R.B.; Cleveland, W.S.; McRae, J.E.; Terpenning, I. STL: A seasonal-trend decomposition. J. Off. Stat. 1990, 6, 3-73.

28. Bigi, A.; Ghermandi, G.; Harrison, R.M. Analysis of the air pollution climate at a background site in the Po valley. J. Environ. Monit. 2012, 14, 552-563. [CrossRef] 
29. Crippa, M.; Oreggioni, G.; Guizzardi, D.; Muntean, M.; Schaaf, E.; Lo Vullo, E.; Solazzo, E.; Monforti-Ferrario, F.; Olivier, J.; Vignati, E. Fossil CO2 and GHG Emissions of All World Countries; Publication Office of the European Union: Luxembourg, 2019.

30. EDGAR v5.0 Global Air Pollutant Emissions. Available online: https://edgar.jrc.ec.europa.eu/overview.php? v=50_AP (accessed on 23 June 2020). [CrossRef]

31. Tan, M.L.; Samat, N.; Chan, N.W.; Roy, R. Hydro-meteorological assessment of three GPM satellite precipitation products in the Kelantan River Basin, Malaysia. Remote Sens. 2018, 10, 1011. [CrossRef]

32. Number of Vehicles On The Road by State, Malaysia, 2008-2015. Available online: http://www.data.gov.my/ data/ms_MY/dataset/bilangan-kenderaan-di-atas-jalan-raya-mengikut-negeri (accessed on 21 June 2020).

33. Laporan Kualiti Alam Sekeliling 2016 (Environmental Quality Report); Department of Environment Malaysia: Putrajaya, Malaysia, 2017.

34. Awang, N.R.; Elbayoumi, M.; Ramli, N.A.; Yahaya, A.S. Diurnal variations of ground-level ozone in three port cities in Malaysia. Air Qual. Atmos. Health 2016, 9, 25-39. [CrossRef]

35. Cooper, O.R.; Parrish, D.; Ziemke, J.; Balashov, N.; Cupeiro, M.; Galbally, I.; Gilge, S.; Horowitz, L.; Jensen, N.; Lamarque, J.-F.; et al. Global distribution and trends of tropospheric ozone: An observation-based review. Elem. Sci. Anth. 2014, 2, 000029. [CrossRef]

36. Anet, J.G.; Steinbacher, M.; Gallardo, L.; Velásquez Álvarez, P.A.; Emmenegger, L.; Buchmann, B. Surface ozone in the Southern Hemisphere: 20 years of data from a site with a unique setting in El Tololo, Chile. Atmos. Chem. Phys. 2017, 17, 6477-6492. [CrossRef]

37. Nair, P.R.; Ajayakumar, R.S.; David, L.M.; Girach, I.A.; Mottungan, K. Decadal changes in surface ozone at the tropical station Thiruvananthapuram $\left(8.542^{\circ} \mathrm{N}, 76.858^{\circ} \mathrm{E}\right)$, India: Effects of anthropogenic activities and meteorological variability. Environ. Sci. Pollut. Res. 2018, 25, 14827-14843. [CrossRef]

38. Fu, Y.; Liao, H.; Yang, Y. Interannual and decadal changes in tropospheric ozone in China and the associated chemistry-climate interactions: A review. Adv. Atmos. Sci. 2019, 36, 975-993. [CrossRef]

39. Guicherit, R.; Roemer, M. Tropospheric ozone trends. Chemosphere Glob. Chang. Sci. 2000, 2, 167-183. [CrossRef]

40. Assareh, N.; Prabamroong, T.; Manomaiphiboon, K.; Theramongkol, P.; Leungsakul, S.; Mitrjit, N.; Rachiwong, J. Analysis of observed surface ozone in the dry season over Eastern Thailand during 1997-2012. Atmos. Res. 2016, 178-179, 17-30. [CrossRef]

41. Ahamad, F.; Latif, M.T.; Tang, R.; Juneng, L.; Dominick, D.; Juahir, H. Variation of surface ozone exceedance around Klang Valley, Malaysia. Atmos. Res. 2014, 139, 116-127. [CrossRef]

42. Nagashima, T.; Sudo, K.; Akimoto, H.; Kurokawa, J.; Ohara, T. Long-term change in the source contribution to surface ozone over Japan. Atmos. Chem. Phys. 2017, 17, 8231-8246. [CrossRef]

43. Parrish, D.D.; Trainer, M.; Buhr, M.P.; Watkins, B.A.; Fehsenfeld, F.C. Carbon monoxide concentrations and their relation to concentrations of total reactive oxidized nitrogen at two rural U.S. sites. J. Geophys. Res. Atmos. 1991, 96, 9309-9320. [CrossRef]

44. Aneja, V.P.; Agarwal, A.; Roelle, P.A.; Phillips, S.B.; Tong, Q.; Watkins, N.; Yablonsky, R. Measurements and analysis of criteria pollutants in New Delhi, India. Environ. Intern. 2001, 27, 35-42. [CrossRef]

45. Goyal, P. Present scenario of air quality in Delhi: A case study of CNG implementation. Atmos. Environ. 2003, 37, 5423-5431. [CrossRef]

46. Coppalle, A.; Delmas, V.; Bobbia, M. Variability of NOx and NO2 concentrations observed at pedestrian level in the city centre of a medium sized urban area. Atmos. Environ. 2001, 35, 5361-5369. [CrossRef]

47. Mavroidis, I.; Ilia, M. Trends of NOx, NO2 and $\mathrm{O} 3$ concentrations at three different types of air quality monitoring stations in Athens, Greece. Atmos. Environ. 2012, 63, 135-147. [CrossRef]

48. Zhang, J.; Ouyang, Z.; Miao, H.; Wang, X. Ambient air quality trends and driving factor analysis in Beijing, 1983-2007. J. Environ. Sci. 2011, 23, 2019-2028. [CrossRef]

49. Gardner, M.W.; Dorling, S.R. Meteorologically adjusted trends in UK daily maximum surface ozone concentrations. Atmos. Environ. 2000, 34, 171-176. [CrossRef]

50. Vingarzan, R. A review of surface ozone background levels and trends. Atmos. Environ. 2004, 38, 3431-3442. [CrossRef] 
51. Pusede, S.E.; Steiner, A.L.; Cohen, R.C. Temperature and recent trends in the chemistry of continental surface ozone. Chem. Rev. 2015, 115, 3898-3918. [CrossRef]

52. Manahan, S.E. Fundamentals of Environmental Chemistry; CRC Press: Boca Raton, FL, USA, 2011.

(C) 2020 by the authors. Licensee MDPI, Basel, Switzerland. This article is an open access article distributed under the terms and conditions of the Creative Commons Attribution (CC BY) license (http://creativecommons.org/licenses/by/4.0/). 